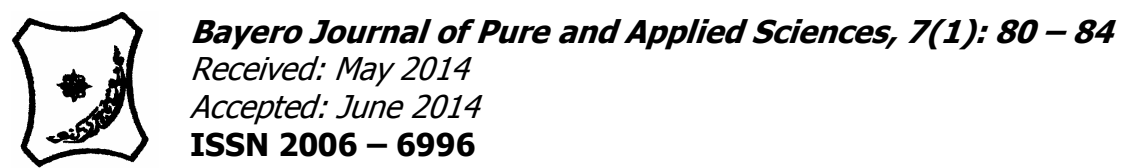

\title{
COMPARISON OF LEVELS OF SOME METALS IN THE WATER AND SEDIMENT FROM CHALLAWA GORGE DAM, KANO, NIGERIA
}

\author{
${ }^{1} *$ Malami, D.I., ${ }^{1}$ Zakaria, Z.I., ${ }^{2}$ Mohammed, M.I. and ${ }^{2}$ Audu, A.A. \\ ${ }^{1}$ Kano State Drugs and Medical Consumable Supply Agency, No. 2 Ibrahim Taiwo Road. Kano State. \\ ${ }^{2}$ Department of Pure and Industrial Chemistry, Bayero University Kano. \\ *Correspondence author: dmalamii@yahoo.com
}

\begin{abstract}
Level of some Metals (Cd,Cr,Mn,Pb,Zn,Na and $K$ ) was seasonally determined in the water and sediments of Challawa Gorge dam.The result obtained showed that the values of the metal contents were generally higher in the dry season than the wet season. The metal contents of the water and sediment were obtained using the nitric acid digestion method. All the metals analyzed except $\mathrm{Na}$ and $\mathrm{K}$ were determined using Atomic Absorption Spectroscopy (flame emission spectroscopic method). Variations in concentrations were found for the heavy metals ranging between (0.01and1.41 $\mathrm{mg} / \mathrm{I})$ in water and (1.0 and $1.64 \mathrm{mg} / \mathrm{kg}$ ) in the sediments. Sodium and potassium were found in concentrations ranging between $7.65 \pm 0.28$ and $11.32 \pm 8.62 \mathrm{mg} / \mathrm{l}$ in water and between $50.32 \pm 18.08 \mathrm{mg} / \mathrm{l}$ and $144.19 \pm 12.09 \mathrm{mg} / \mathrm{kg}$ in the sediments respectively. The statistical comparison of the values between the wet and dry season in water as well as those in sediment shows no significant difference at P>0.05. All the metals were found to be within the permissible limits as recommended by WHO/NOAA for quality water and sediments except for the levels of iron (Fe) in water which was found to be above the acceptable limit. The sediments contained higher concentration of heavy metals than the water. This may be attributed to the fact that sediments usually serves as repositories in an aqueous environment. Keywords: Heavy metals, sediment, wet season, dry season, water.
\end{abstract}

INTRODUCTION

Water is everywhere, but little is available to drink. The total amount of water on the earth is constant, it neither increases nor decrease but may change location due to climatic changes, human activities or both. Water for domestic, municipal, and industrial use can be obtained from two principle sources, the surface and underground waters (Mendie, 2005).

Adequate fresh water supply is the most important prerequisite for sustaining human life, maintaining ecosystem and ecodiversities and achieving sustainable development. The need for humanity to adequate fresh water for survival, social and economic development in enormous, and will remain a major national, regional and international priority in the years to come (Mendie, 2005).

The pollution of aquatic environment has become a worldwide problem in recent years, because of its toxic effects on living organisms (Macfarlane and Burchett, 2000). Among environmental pollutants, heavy metals are of particular concern, due to their potential toxic effect and ability to bio accumulates in the ecosystem (Censi et al, 2006).

Heavy metals in aquatic ecosystems are usually monitored by measuring their concentrations in water, sediments and biota (Camusso and Baitstrini, 1995), which generally exist in low levels in water and attain considerable concentration in sediment and biota (Namming and Wilhm, 1976).

Dams are being polluted by indiscriminate disposal of sewage, industrial wastes and human activities. Dams are always the victims of the negative impacts of urbanisation as most water bodies become contaminated due to in co-operation of untreated solid and liquid wastes (Jahabhaye et al., 2008). Different regulations put in place to protect the marine environment in Nigeria have not been effective in controlling the indiscriminate dumping of effluents into open water bodies. These effluents range from chloride, phosphate, oil and grease, nitrates and heavy metals to name but a few. The heavy metals present in most Nigerian rivers found in concentrations well above acceptable and permissible level are lead, copper, zinc, nickel, chromium, cadmium and iron (Olayinka and Alo, 2004).

Heavy metals contamination is a major concern because of their toxicity and threat to human life and his environment. This alongside with the economic importance of Challawa Gorge dam, was what gave rise to the conducting of this research. The values obtained from this research would shade more light on the background levels of metals in the water and sediments of the Challawa Gorge Dam, adding to the effective monitoring of both environmental quality and the health of the organisms inhabiting the dam ecosystem.This study therefore aimed at determining seasonally, the level of some metals in the water and sediment of Challawa Goje Dam, so as to check whether change in season would lead to variation in concentrations of the metals.

\section{MATERIALS AND METHODS}

\section{Study Area}

The Challawa Gorge dam is in Kano state in the Northwestern part of Nigeria. The dam is located on latitude $11^{\circ} 44^{\circ} 34^{\prime \prime}$ and longitude $8^{\circ} 1^{\circ} 2^{\prime \prime}$, about $90 \mathrm{~km}$ southwest of Kano city (Figure 1). 
It is a major reservoir on the Challawa River. The dam was built in 1990-1992 using rock fill construction. The dam is designed to create a multipurpose reservoir to serve the water needs of downstream area in Kano, Jigawa, Yobe and Borno states. It is $42 \mathrm{~m}$ high and $7.804 \mathrm{~km}$ in length. The dam has a full storage capacity of $904,000,000 \mathrm{~m}^{3}$. The direct catchment area is $3857 \mathrm{~km}^{2}$ (Anim et al, 2011).

\section{Sample Collection}

Water samples were collected from five designated points along the course of the Challawa Gorge Dam in duplicate in 2 litre and 5 litre plastic containers twice during the wet season (Aug/Sept 2011) and dry season (March/April 2012). Samples were labeled Daura (DWA), Ganji (DWB), Dadinkowa,( DWC), Sakarma (DWD) and Turawa (DWE) respectively. And these designated point of sampling were chosen for easy identification of the sample area. The sediment samples were also collected from five designated points along the course of the Dam in clean polythene bags. The sediments were collected from the same sampling points as water so as to establish a good representative of the dam. Samples of sediment were coded SA, SB, SC, SD, and SE respectively. The water samples were transported to the laboratory in boxes containing ice (Anim et al, 2011).
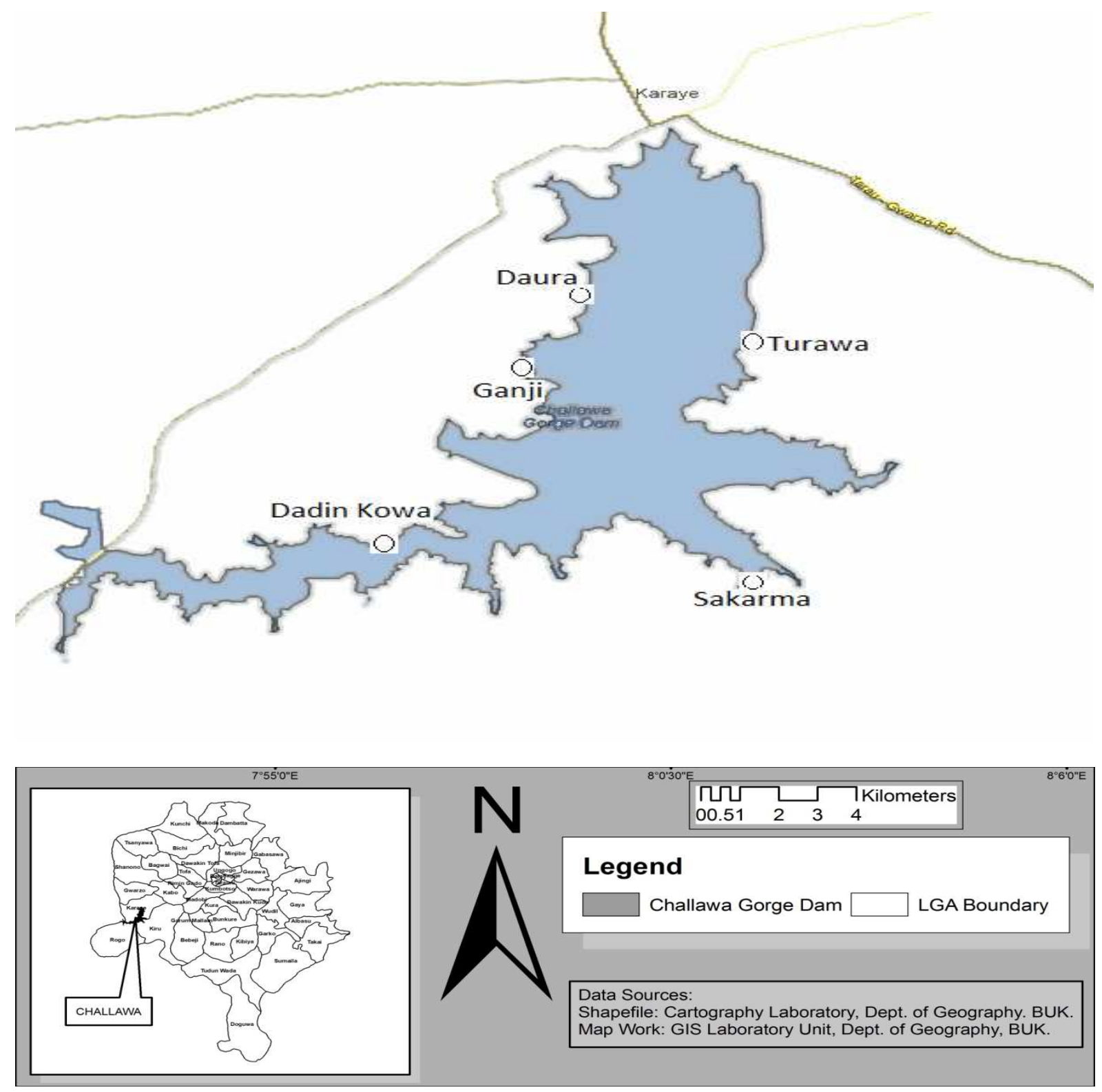

Figure 1: A map of Challawa Gorge Dam showing sampling sites.

\section{Sample Pre-treatment}

The samples for heavy metals determination were treated with $5 \mathrm{~cm}^{3}$ concentrated $\mathrm{HNO}_{3}$ per liter of sample to prevent metals from adhering to the walls of the container (APHA, 1985). 


\section{Digestion of Sample}

Water sample: - The water sample, $\left(100 \mathrm{~cm}^{3}\right)$ was transferred into a beaker and $5 \mathrm{~cm}^{3}$ concentrated $\mathrm{HNO}_{3}$ was added. The beaker with the content was placed on a hot plate and brought to a slow boil. The solution was allowed to evaporate to about $20 \mathrm{~cm}^{3}$ volumes. The beaker was cooled and another $5 \mathrm{~cm}^{3}$ concentrated $\mathrm{HNO}_{3}$ was added and covered with a watch glass and the heating continued, One (1) $\mathrm{cm}^{3}$ of $\mathrm{HNO}_{3}$ was again added until the solution appeared light colored and clear. The beaker wall and watch glass were washed with distilled water and the sample was filtered to remove any insoluble materials. The volume was made up to $100 \mathrm{~cm}^{3}$ mark with distilled water in a volumetric flask (APHA, 1985).

Sediment sample: - The sediment sample was air dried in the laboratory, grounded using pestle and mortar and sieved with $200 \mathrm{~mm}$ sieve to obtain a fine powder. A quantity (1.0 gram) of each dried sediment sample was digested for $30 \mathrm{~min}$ with 30 litres of $6 \mathrm{M}$ $\mathrm{HNO}_{3}$ acid. The solution was filtered through a Whatman 40 filter paper into $100 \mathrm{~cm}^{3}$ volumetric flask and was made up to mark with deionized water, 5 litres of resultant solution was transferred into 50 litres volumetric flask and made up to mark with deionized water (Ayodele and Gaya, 1994).

\section{Elemental Analysis}

All the metals ( $\mathrm{Cd}, \mathrm{Cr}, \mathrm{Mn}, \mathrm{Pb}, \mathrm{Zn}$ ) except $\mathrm{Na}$ and $\mathrm{K}$ were determined using an Atomic Absorption Spectrophotometer model VGB 210 SYSTEM, Buck Scientific. $\mathrm{Na}$ and $\mathrm{K}$ are analyzed using Flame Photometer (Jenway, model PFP7). The result of each sample was the average of three sequential readings. Deionized water used as blank was treated using the same procedure.

\section{RESULTS AND DISCUSSION}

The levels of heavy metals determined in the water and sediment samples showed variations during the wet and dry seasons but statistical comparison indicates no significant difference $(P>0.05)$. The result showed that the dry season values were observed to be relatively higher than those of the wet season.

The concentration of the metals shows trend of being higher during the dry season. The mean concentration of cadmium in the samples was found to be $0.01 \pm$ $0.0 \mathrm{mg} / \mathrm{l}$ in water (Table 1 ) and $4.13 \pm 0.01 \mathrm{mg} / \mathrm{kg}$ in the sediment (Table 1 ). The maximum permissible limit of cadmium in drinking water is $0.01 \mathrm{mg} / \mathrm{l}$ as set by WHO (2003) while that of the sediment is $4.9 \mathrm{mg} / \mathrm{kg}$ as set by NOAA (2009) as shown in tables 1below.

When these values were compared with these international standards they were found to be within acceptable limits. The results obtained agreed with reports by Ozturk et al, (2009) on the determination of heavy metals in water, fish and sediments of Avsar dam in Turkey.

Chromium is also essential for organisms as a micro nutrient in form of fat and carbohydrate metabolism.
Higher concentration of chromium may lead to cancer. The mean concentration of chromium obtained was $0.04 \pm 0.01 \mathrm{mg} / \mathrm{l}$ in water (Table 1) and 9.57 \pm 2.75 $\mathrm{mg} / \mathrm{kg}$ in sediment (Table 1). The maximum acceptable concentration of chromium in drinking water is $0.05 \mathrm{mg} / \mathrm{l}$ as set by WHO (1993) and $26.0 \mathrm{mg} / \mathrm{kg}$ for sediment as set by NOAA (2009) as shown in Tables 1 below. The values obtained when compared with these standards fall within the acceptable limits. The result obtained agreed with reports by Ozturk et al, (2009) on the determination of heavy metals in water, fish and sediments of Avsar dam in Turkey. The concentration of iron was found to be $1.35 \pm 0.06 \mathrm{mg} / \mathrm{l}$ in water and $19.31 \pm 5.60 \mathrm{mg} / \mathrm{kg}$ in sediment (Table 1 ). The values obtained for water were found higher than the recommended value of $0.3 \mathrm{mg} / \mathrm{l}$ as set by SON (2007). This may be as a result of reduction of ferric $\left(\mathrm{Fe}^{3+}\right)$ to ferrous $\left(\mathrm{Fe}^{2+}\right)$ in the presence of organic matter where by the latter is readily soluble and also different anthropogenic inputs such as agricultural activities around the dam (SON, 2007).

The concentration of manganese was found to be $0.24 \pm 0.05 \mathrm{mg} / \mathrm{l}$ in water (Table 1 ) and $6.13 \pm 1.88$ $\mathrm{mg} / \mathrm{l}$ in sediment (Table 1 ). The maximum permissible limit of manganese set by WHO is $0.4 \mathrm{mg} / \mathrm{l}$ in water. The values obtained in this study were found to be below the acceptable limit set for drinking water as shown in Tables above. The results agreed with reports by Adegoke et al, (2003) on monitoring the effect of pollution in twelve selected water dams in Osun state, Nigeria.

The maximum acceptable concentration of lead in drinking water is $0.05 \mathrm{mg} / \mathrm{l}$ according to WHO (1993), while that of sediment is $35.8 \mathrm{mg} / \mathrm{kg}$ as set by NOAA (2009) as shown in Tables 1above.

The mean values of lead in this study were found to be $0.02 \pm 0.01 \mathrm{mg} / \mathrm{l}$ in water and $2.05 \pm 0.42 \mathrm{mg} / \mathrm{kg}$ in the sediment as shown in Table 1 . When these values were compared with the standards they were found to be within the acceptable limits as also shown in Tables 1above. The result obtained in this study agreed with reports by Eletta (2007) on the determination of some trace metals in Asa River, Ilorin, Nigeria.

The concentration of zinc obtained was $0.65 \pm$ $0.18 \mathrm{mg} / \mathrm{l}$ in water and $40.25 \pm 10.75 \mathrm{mg} / \mathrm{kg}$ in sediment. The values obtained in this study were found to be within the maximum permissible limit of $3 \mathrm{mg} / \mathrm{l}$ set by SON (2007) for drinking water and $120 \mathrm{mg} / \mathrm{kg}$ for sediment as set by WHO (2003).

The concentrations of sodium and potassium in the water and sediment were found to be $14.28 \pm 5.66 \mathrm{mg} / \mathrm{l}$ and $144.18 \pm 12.09 \mathrm{mg} / \mathrm{kg}$ for sodium and $7.65 \pm 0.28 \mathrm{mg} / \mathrm{l}$ and $50.32 \pm 18.08 \mathrm{mg} / \mathrm{kg}$ for potassium respectively. The values obtained for sodium in water were found to be within the safe limit of $200 \mathrm{mg} / \mathrm{l}$ set by SON (2007) as shown in Table 1. 
Table 1: Metal concentrations in water from Challawa Gorge Dam Kano and sediment compared with standards*

\begin{tabular}{|c|c|c|c|c|c|c|c|c|c|}
\hline S/NO & METALS & $\begin{array}{l}\text { WET SEASON } \\
\text { FOR WATER } \\
(\mathrm{mg} / \mathrm{l})\end{array}$ & $\begin{array}{l}\text { DRY SEASON } \\
\text { FOR WATER } \\
(\mathrm{mg} / \mathrm{l})\end{array}$ & $\begin{array}{l}\text { DRY SEASON } \\
\text { AND WET } \\
\text { SEASON FOR } \\
\text { WATER } \\
(\mathrm{mg} / \mathrm{l})\end{array}$ & $\begin{array}{l}\text { WET SEASON FOR } \\
\text { SEDIMENT } \\
(\mathrm{mg} / \mathrm{kg})\end{array}$ & $\begin{array}{l}\text { DRY SEASON FOR } \\
\text { SEDIMENT } \\
(\mathrm{mg} / \mathrm{kg})\end{array}$ & $\begin{array}{l}\text { DRY SEASON } \\
\text { AND WET } \\
\text { SEASON FOR } \\
\text { SEDIMENT } \\
(\mathrm{mg} / \mathrm{kg})\end{array}$ & $\begin{array}{c}\text { WHO } \\
(2003) / S O N \\
(2007) \\
\text { FOR WATER } \\
(\mathrm{mg} / \mathrm{l})\end{array}$ & $\begin{array}{c}\text { NOAA } \\
(2009) / \text { WHO } \\
(2003) \text { FOR } \\
\text { SEDIMENT } \\
(\mathrm{mg} / \mathrm{kg})\end{array}$ \\
\hline 1 & Cd & $0.01 \pm 0.00$ & $0.01 \pm 0.00$ & $0.01 \pm 0.00$ & $4.12 \pm 0.01$ & $4.13 \pm 0.01$ & $4.13 \pm 0.01$ & 0.01 & 4.9 \\
\hline 2 & $\mathrm{Cr}$ & $0.03 \pm 0.01$ & $0.04 \pm 0.00$ & $0.04 \pm 0.01$ & $6.82 \pm 2.75$ & $12.32 \pm 2.75$ & $9.57 \pm 2.75$ & 0.05 & 26.0 \\
\hline 3 & $\mathrm{Fe}$ & $1.29 \pm 0.06$ & $1.41 \pm 0.06$ & $1.35 \pm 0.06$ & $13.72 \pm 5.60$ & $24.9 \pm 5.60$ & $19.31 \pm 5.60$ & 0.30 & - \\
\hline 4 & Mn & $0.20 \pm 0.05$ & $0.285 \pm 0.05$ & $0.24 \pm 0.05$ & $4.25 \pm 1.88$ & $8.00 \pm 1.88$ & $6.13 \pm 1.88$ & 0.40 & - \\
\hline 5 & $\mathbf{P b}$ & $0.01 \pm 0.01$ & $0.03 \pm 0.01$ & $0.02 \pm 0.01$ & $1.64 \pm 0.42$ & $2.47 \pm 0.42$ & $2.05 \pm 0.42$ & 0.05 & 35.8 \\
\hline 6 & $\mathrm{Zn}$ & $0.47 \pm 0.18$ & $0.83 \pm 0.18$ & $0.65 \pm 0.18$ & $29.5 \pm 10.75$ & $51.0 \pm 10.75$ & $40.25 \pm 10.75$ & 3.00 & 120 \\
\hline 7 & $\mathrm{Na}$ & $8.62 \pm 2.70$ & $19.94 \pm 8.62$ & $14.28 \pm 5.66$ & $132.09 \pm 12.09$ & $156.28 \pm 12.09$ & $144.18 \pm 12.09$ & 200 & - \\
\hline 8 & $\mathbf{K}$ & $7.37 \pm 0.28$ & $7.92 \pm 0.28$ & $7.65 \pm 0.28$ & $32.24 \pm 18.08$ & $68.4 \pm 18.08$ & $50.32 \pm 1808$ & Not stated & - \\
\hline
\end{tabular}

$*$ Values are the average of three replicates on each treatment \pm SD.

Too much sodium has been identified as a risk factor for high blood pressure (Gupta et al., 2009). Potassium occurs in various minerals, from which it may dissolve into water through weathering processes. The levels of sodium and potassium may be as a result of run offs from surrounding farmlands. Although potassium may cause some health effects in susceptible individuals, its intake from drinking water is well below the level at which adverse health effects may occur. In a similar study, Kucheker et al. (2001) recorded values of $1.98-3.92 \mathrm{mg} / \mathrm{l}$ for sodium and $1.33-2.4 \mathrm{mg} / \mathrm{l}$ for potassium.

Seasonal factors such as high volume of rain which lead to dilution and farming activities around the dam are the major reasons behind the seasonal variations in the parameters and metal levels. Generally, the level of all the metals in the samples analyzed was found in the magnitude of sediment greater than in water. This may be attributed to the fact that sediments usually serve as repositories in aqueous environment (Bower, 1979).

\section{CONCLUSION}

Conclusively, Challawa Gorge dam is not within an industrial area and thus it is not expected that the values of its metals in the water and sediment to exceed acceptable limits. The main source of pollution in the dam is from laundry activities and agricultural activities. The metal levels ( $\mathrm{Cd}, \mathrm{Cr}, \mathrm{Fe}, \mathrm{Mn}, \mathrm{Pb}, \mathrm{Zn}, \mathrm{Na}$ and $\mathrm{K}$ ) determined in the water of the dam were found to be higher during the dry season than the wet season. This may be attributed to reduction in the volume of water during the dry season. The metals studied in the water and sediments were found to be within the acceptable limits of WHO (2003), SON (2007) and NOAA (2009) for drinking water and quality sediment.

It can be therefore concluded that the Challawa Gorge dam is safe for domestic and irrigation uses.

\section{RECOMMENDATIONS}

Water quality monitoring should be check at least twice a year in order to ascertain the quality of the water at regular intervals so as enable the evaluation of possible trace metals build-up in the cultivated crops, sediments and aquatic animals in the water. 


\section{REFERENCES}

Adegoke, J.A., Sunmonu, L.A. and Lateef, T.A. (2003). Monitoring of water pollution in twelve selected water dams in Osun state of South Western Nigeria. Nigerian Journal of Health and Biomedical science, 3(1):50-57.

American Public Health Association (APHA) (1985). American Water Work Methods For the Examination of Water and Wastewater $16^{\text {th }}$ Edition. American Public Health Association Inc.New York.

Anim, A. K., Ahialey, E. K., Duodu, G.O., Ackah, M. and Bentil, N. (2011). Accumulation Profile of Heavy Metals in fish samples from Nsawam, Along the Densu River, Ghana. Research Journal of Environmental and Earth Sciences, 3(1): 56-60.

Ayodele, J T. and Gaya, U M (1994). Determination of Lead in Street Dust to its pollution in Kano Municipal. Spectr j. 1(2): 92-96.

Bower, H. J. (1979). Heavy Metals Pf Foundry cover Cold Spring New York; Environ. Sci. Technol. 13:683-687.

Camusso, M.V. and Baitstrini, L. R. (1995). Bioaccumulation of Trace Metals in rainbow trout, Ecotox. Environ. safe. 31:133-141.

Censi, P. S., Saiano, S. E., Sprovieri, F. M., Mazzalo, M. S., Nardone, S. G., Di Geronimo, S. I., Puntoro, R. and Ottonello, D. (2006). Heavy metals in coastal water systems. A case study from the northwestern Gulf of Thailand, Chemosphere, 64: 1167-1176.

Eletta, O. A. A. (2007); Determination of some trace metals in Asa River using AAS and XRF techniques, Intl. J. Phy. Sci. 2(3): 50-56.

Gupta, P., Choudry, R. And Vishwakarma, M. (2009): Assessment of Water Quality of Kerwa and Kaliosote Rivers at Bhopal Distric for irrigation purpose. International Journal of Theoretical \& Applied Sciences, 1(2): 27-30.

Jahabhaye, U. M., Pentewar, M. S. and Hiware, C. J. (2008). A Study on Physicochemical Parameters of a reservoir, Sawana, Hingoli, Disrict, Aharashtra. J. Aqua.Biol, 23(2): 5660.
Kuchekar, K., Viswas, B., Gaikwad., S. R. and Pramod N. (2001): Monitoring of Physicochemical Parameters and Quality Assessment of Water for Bhandaradara Reservoir. Der Chemica Sinica, 2(4): 229-234.

Macfarlane, G. B., Burchett, M. D. (2000). Cellular distribution of $\mathrm{Cu}, \mathrm{Pb}$ and zinc in the Grey Mangrove Avicemnia marina (forsk), Vierh Aqautic Botanic, 68: 45-59.

Mendie, U. (2005). The Theory and practice of clean water production for domestic and industrial use. First edition, Lacto-Medicals Publishers. $6 \mathrm{~A}$ Bola Shadipe Street, Lagos-Nigeria. Pp 20 $-40$

Namming, H. N. and Wilhm, J. (1976). Effects of high discharge and oil refinery cleanup Operation, Heavy Metals in Water and Sediments in skeleton creek. Proceedings of the Oklahoma Academy of Science, 56: 133-138.

NOAA, National Oceanic and Atomspheric Administration (2009) SQUIRT, Screening QUICK Reference Tables in sediment, http;// response. Restoration. NOAA.gov/bookshelf/122 New-SQUIRTS.Pdf (Online Update; 23.03. 2009).

Olayinka, K. O. and Alo, B. I. (2004). Studies on industrial pollution in Nigeria: the effects of textile effluents on the quality of groundwater in some parts of Lagos. Nigerian Journal of Health and Biomedical science, 3(1):44-50.

Ozturk M., Ozuzen G., Minareci, O, and Manareci E. (2009). Determination of Heavy Metals in fish, water and sediments of Avsar dam lake in Turkey. Iran J. Environ. Health Sci, Eng., 6(2):73-80.

Standard Organization of Nigeria (SON, 2007) Specification for potable water; plot 1678, Lome Street Wuse Zone 7, Abuja-Nigeria.

World Health Organization(1993). Guidelines for Drinking Water Quality Recommendations, Vol. $1,2^{\text {nd }}$ ed, Geneva.

World Health Organization(2003). Guidelines for Drinking Water Quality Recommendations, Vol. $1,2^{\text {nd }}$ ed, Geneva. 